\title{
BUDAYA TUTUR DIGITAL DALAM PERSONAL BRANDING MELALUI STIKER LINE GENERASI MILLENIAL
}

\author{
Sri Seti Indriani ${ }^{1}$, Dhita Prasanti ${ }^{2)^{*}}$ \\ ${ }^{1)}$ Ilmu Komunikasi, Universitas Padjadjaran \\ ${ }^{2)}$ Ilmu Komunikasi, Universitas Padjadjaran
}

\begin{abstract}
Millenials are seen using social media more often which has replaced forms of communication to become digital speech. Personal branding through digital speech in the social media life has a significant role in representing themselves. Personal branding is constructed from culture, environment and how individuals are brought up by. Stickers provided in Line application is one of the digital speech culture which are now oftenly used actively in communicating. Millenials tend to use these stickers so they have an ability on how they want others to portrait them. The research focuses on : (1) to describe how these millennials use these stickers to construct a personal branding in Line group, (2) to describe the reasons and use of these stickers in line. A qualitative approach in ethnography virtual method is used, using in-depth interview and observation. The result of this research shows that (1) they buy stickers that represent themselves and their feelings towards a subject to support their personal branding in Line group (2) millenials use stickers to support their meaning in conversations, when they can't find the verbal words to describe their feelings, when they are forced to respond fast, and because the stickers are unique and funny.

Key words: Stickers, Millenials, Personal Branding, Media Social and Line Group
\end{abstract}

\begin{abstract}
ABSTRAK
Generasi milenial menggunakan media sosial yang telah menggantikan bentuk-bentuk komunikasi menjadi sebuah budaya tutur digital. Personal brandingmelalui tutur digital dalam sosial media sepertinya tengah memiliki peran yang penting dalam mempresentasikan identitas seseorang. Personal branding itu sendiri dikonstruksi lewat budaya, lingkungan dan bagaimana seseorang dididik dalam kehidupannya. Penggunaan stiker-stiker yang terdapat dalam aplikasi Line grup merupakan salah satu budaya tutur digital yang semakin hari memiliki peran aktif dalam berkomunikasi. Generasi ini lebih senang menggunakan stiker-stiker ini untuk membentuk gambaran dirinyasekaligus personal brandingnya. Fokus penelitian ini adalah untuk (1) menggambarkan bagaimana generasi milenial ini menggunakan stiker-stiker ini untuk mengkonstruksi sebuahpersonal branding, dan (2) menggambarkan alasan penggunaan stiker-stiker tersebut. Metodelogi penelitian yang diggunakan adalah pendekatan kualitatif dengan metode etnografi virtual. Teknik pengumpulan data menggunakan wawancara, observasi dan studi dokumentasi. Hasil penelitian menunjukkan : (1) mereka biasanya membeli stiker yang dapat mempresentasikan dirinya dan perasaan mereka pada sebuah subjek pembahasan untuk mendukung personal branding mereka dalam grup Line, (2) Generasi milenialmenggunakan stiker untuk; mendukung maksud mereka dalam sebuah diskusi, ketika mereka tidak dapat menjelaskan sesuatu lewat perkataan verbal, ketika mereka terpaksa untuk menanggapi sesuatu dengan cepat dankarena stiker tersebut dianggap unik dan lucu

Kata Kunci: Stiker, Generasi millennium, Personal branding, Media sosial dan Grup Line
\end{abstract}

\footnotetext{
* Korespondensi Penulis

Email: rahadianindri@gmail.com dithaprasanti@gmail.com
} 


\section{PENDAHULUAN}

Generasi milenial mau tidak mau harus mengikuti perkembangan jaman, termaksud penggunaan aplikasi chat yang difasilitasi oleh berbagai media sosial seperti Line. Perkembangan jaman ini telah memberikan gaya baru dalam berinteraksi dengan sesama. Tidak lagi hanya berinteraksi secara langsung namun secara on-line atau lewat media sosial. Dengan perubahan ini, pencitraan diri (Personal branding) dalam media sosial dianggap penting untuk beberapa remaja karena mempresentasikan dirinya. 'pencitraan itu penting asal $g a$ berlebihan dan caranya yang bener. Itu buat self branding' (Cecep, 2019). Lutfi merasa bahwa pada era digital ini manusia menilai manusia lain dari perilaku seseorang dalam sosial medianya (Arief, 2019)

Menurut 'Daily time spent' (2016), manusia rata-rata menghabiskan sekitar 118 menit per harinya pada media sosial, dan pada kalangan remaja menurut Willet (2016) menghabiskan waktunya bahkan lebih, yaitu sekitar Sembilan jam per harinya (Johnson, 2017). Seperti yang dikutip oleh Noviandari (2015) pengguna internet di seluruh dunia mencapai angka 31,7 miliar dan dari tahun ke tahun jumlah pengguna internet tumbuh hingga 7,6 persen. Sedangkan untuk pengguna media sosial sendiri mencapai angka 2,2 miliar dengan pengguna mobile mencapai 3,7 miliar (Sherlyanita \& Rakhmawati, 2016).

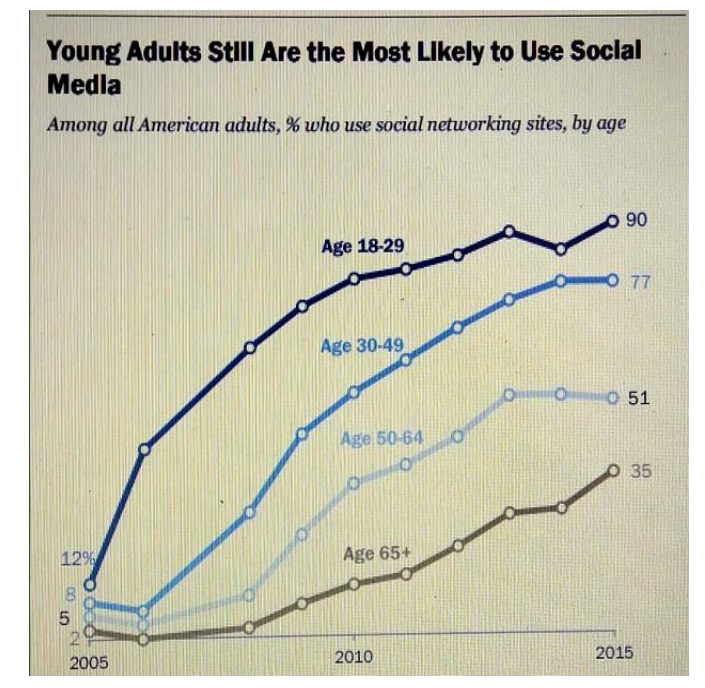

Gambar 1: Presentase pengguna media sosial berdasarkan umur dari tahun 2005-2015

(sumber: Pew Research Center surveys)

Gambar 1 menunjukkan bahwa umur memiliki relasi yang kuat dengan pengguna media sosial. Mereka yang berumur 18-29 tahun paling memiliki tendensi yang tinggi dalam menggunakan media sosial (Perrin, 2015). Data tersebut mengasumsikan bahwa pengguna media sosial tertinggi adalah mereka yang merupakan generasi milenial. Umur 18-29 adalah mereka yang lahir pada awal tahun 1990-an hingga awal 2000-an. Pernyataan ini juga membuktikan mengapa personal branding dalam media sosial memiliki peran yang cukup signifikan. Hampir dapat diasumsikan bahwa kehidupan generasi milenial ini lebih banyak dihabiskan melalui media sosial.

Setiap orang memiliki personal brand, namun tidak cukup hanya dengan memilikinya, namun harus beriringan dengan bagaimana seseorang memanage sebuah promosi yang baik mengenai dirinya agar di kenal baik 
oleh orang lain (Karaduman, 2013). Personal branding memang sudah dikenal lama untuk mempromosikan seseorang mengenai kualitasnya yang bertujuan untuk meningkatkan karirnya. Banyak penelitian yang sudah dilakukan mengenai hal ini, namun masih jarang penelitian-penelitian yang berhubungan dengan personal branding yang dilakukan melalui media sosial.

Penelitian ini lebih
memfokuskan padapersonal branding yang dilakukan generasi milenial dalam media sosial aplikasi Line grup. Line merupakan platform media sosial yang memberikan fasilitas stiker pagi pengguna untuk memudahkan mereka mengekspresikan dirinya. Berdasarkan pra-riset ditemukan bahwa personal branding atau self branding memiliki peran penting untuk dirinya, tidak hanya dalam kelompok-kelompok kerja namun juga penting untuk pergaulan mereka khususnya ketika berinteraksi dalam media sosial. Stiker-stiker yang terdapat dalam aplikasi chat Line grup ini tidak menutup kemungkinan bagi pengguna untuk memperkuat personal branding pengguna Line.

Pemaparan di atas menunjukkan bahwa fokus penelitian ini bertujuan untuk menggambarkan bagaimana para generasi milenial menggunakan stikerstiker sebagai budaya tutur mereka dalam media sosial. Maka pertanyaan penelitiannya sebagai berikut:

1. Bagaimana generasi milenial ini menggunakan stiker-stiker ini untuk mengkonstruksipersonal brandingmereka.

2. Bagaimana alasan-alasan pemilihan danpenggunaan stiker-stiker tersebut.

\section{TINJAUAN PUSTAKA}

Generasi milenial itu seperti yang dikutip oleh kominfo (2016) merupakan generasi yang akrab disebut sebagai generasi $\mathrm{Y}$ yang juga dikenal dengan sebutan generation me atau echo boomers. Para pakar menggolongkannya generasi $\mathrm{Y}$ terbentuk bagi mereka yang lahir pada 1980-1990, atau pada awal 2000 (Republika, 2016). Pada penelitian Lancester \& Stillman (2002) memiliki sikap yang realistis, mereka sangat menghargai perbedaan, lebih memilih bekerja sama daripada menerima perintah, dan sangat pragmatis ketika memecahkan persoalan. Lancerster \& Stillman juga mengatakan dalam lingkungan pekerjaan, generasi milenial ini memiliki rasa optimis yang tinggi, fokus pada prestasi, percaya diri, percaya pada nilai-nilai moral dan sosial, serta menghargai adanya keragaman (Putra, 2016). Generasi milenial merupakan generasi modern yang aktif bekerja, penelitian, dan berpikir inovatif tentang organisasi, memiliki rasa optimism dan kemauan untuk bekerja dengan kompetitif, terbuka, dan fleksibel (Ambarwati \& Raharjo, 2018).

Generasi $\mathrm{Y}$ atau generasi milenial memahami kebutuhan media sosial, karena generasi Y merupakan generasi yang tumbuh pada era internet booming. Mereka banyak menggunakan teknologi komunikasi instan seperti email, SMS, instant messaging dan media sosial (Putra, 2016).

Kaplan dan Haenlein dalam Karaduman (2013) mendeskripsikan media sosial sebagai sebuah kelompok yang didasari oleh aplikasi-aplikasi internet yang membangun fondasi ideologis dan teknologi Web 2.0 dan memungkinkan penciptaandan pertukaran dari pengguna. Media sosial merupakan salah satu bukti kemajuan teknologi komunikasi yang menjadikan dunia seperti layaknya sebuah lapangan kecil dimana orang-orang berinteraksi. 
"The compression of time and space, due to convergence of the new media and globalization, has shrunk the world into into a much smaller interactive field"(Sawyer, 2011).

Rogers (1986) mengidentifikasi tiga karakter utama yang menandai kehadiran teknologi informasi dan komunikasi, tiga karakter tersebut adalah: (1) interactivity, kemampuan media dalam menginteraksikan penggunanya layaknya ia berinteraksi secara face to face. (2) de-massification, kosumen memiliki tanggung jawab penuh dalam mengontrol dan mendistribusikan pesan secara missal. (3) Asynchronous, yang mengarah pada kehendak pengguna dalam mempertukarkan informasi secara cepat (Arif, 2012). Subjek penelitian merupakan mereka yang bergenerasi milenial yang secara aktif menggunakan media sosial aplikasi Line grup. Para informan ini memiliki kemampuan untuk secara terus menerus berinteraksi dan bertukar informasi seceat mungkin layaknya interaksi face to face tanpa melihat batasan tempat dan waktu. Interaksi yang terus dan menerus tanpa batasan waktu dan tempat ini menjadikan para milenial harus berupaya membangun citra dirinya baik agar tutur bahasa yang dilakukannya melalui media sosial tersebut kredibel dan dapat dipercaya (reliable). Citra diri tersebut secara terus menerus diupayakan dikonstruksi sedemikian rupa agar memiliki citra diri yang baik di lingkungan grup Line tersebut.

Berger danLuckmann, sebagaimana dibahas oleh Basrowi dan Sukidin (2002), merupakan teori yang menekankan bahwa realitas merupakan sesuatu yang dikonstruksikan oleh manusia itu sendiri. Adapun beberapa pijakan pemikiran teori konstruksi Berger dan Luckmann, yang dibahas oleh Basrowi dan Sukidin (2002:194), salah satunya adalah bahwa realitas sosial merupakan konstruksi sosial yang diciptakan individu, dimana individu dianggap sebagai manusia bebas yang melakukan hubungan dengan manusia lainnya. Individu adalah penentu dalam dunia sosialnya yang dikonstruksi berdasarkan kehendaknya. Individu bukan korban fakta sosial, namun sangat kreatif dalam mengkonstruksi dunia sosialnya. Pemaparan tersebut mengasumsikan bahwa para generasi milenial ini memiliki kebebasan secara kreatif dalam menentukan personal brandingnya dalam media sosial khususnya dalam line grup tempat mereka berkumpul menjadi satu.

Internalisasi budaya dalam generasi milenial pengguna media sosial aplikasi line grup terjadi melalui sebuah proses yang panjang. Budaya yang ada dalam diri mereka masing-masing kemudian terlihat dalam budaya tutur yang mereka gunakan dalam media sosial, dalam hal ini pemilihan stiker-stiker. Internalisasi itu sendiri merupakan penyerapan atau proses internalisasi realitas objektif mereka ke dalam kesadaran mereka, sehingga terbentuknya subjektivitas individu (Basrowi \& Sukidin, 2002). Hal ini mengasumsikan bahwa subjektivitas individu ini dipengaruhi oleh struktur dunia sosial.

Personal branding yang dikonstruksi ini tidak lepas dari teori-teori identitas. Generasi milenial mencoba membentuk sebuah identitas dalam media sosial melalui stiker-stiker yang dapat menjadikan identitas mereka. Waterman (1984) menjelaskan bahwa identitas berarti memiliki gambaran diri yang jelas meliputi sejumlah tujuan yang ingin dicapai, nilai, dan kepercayaan yang dipilih oleh individu tersebut. Teori 'the looking-glass self' yang dikemukakan oleh Cooley dalam Mulyana (2001) mengatakan bahwa konsep-diri individu secara signifikan 
ditentukan oleh apa yang ia pikirkan tentang pikiran orang lain mengenai dirinya, sehingga apa yang menjadi respond dari orang lain terhadap dirinya diinternalisasikan secara subjektif kemudian dijadikan sebuah konsep akan dirinya, yang kemudian tumbuh berkembang menjadi sebuah identitas untuk dirinya.

Personal branding merupakan proses ketika seseorang dan karirnya ditandai sebagai merek, ini secara langsung dimaksudkan untuk menciptakan asset dan ekuitas merek yang berkaitan dengan seseorang atau individu tertentu (Karaduman, 2013). 'An individual's personal Brand is a reflection of his or her skills, abilities and lifestyle' seperti yang dikutip oleh Gehl (2011), Hearn (2008) dan Peters (1997) dalam Johnson (2017) bahwa sebuah personal brand seseorang merupakan refleksi kompetensi, keahlian dan kehidpan seseorang.

Socrates dalam Karaduman (2013) mengatakan "The way to gain a good reputation is to endeavor to be what you desire to appear", dengan terjemahan bebasnya adalah bahwa ketika seseorang ingin mendapatkan sebuah reputasi yang baik adalah dengan cara berusaha keras untuk menjadi apa yang diinginkan untuk terlihat. Maka dengan pernyataan tersebut dapat diasumsikan bahwa stiker-stiker Line yang digunakan kelompok remaja yang tergabung dalam sebuah Line grup ingin memunculkan sebuah identitas lewat stiker tersebut dengan tujuan agar mendapatkan sebuah reputasi yang baik dalam media sosial tersebut.

\section{METODE PENELITIAN}

Metode penelitian yang digunakan adalah metode penelitian kualitatif dengan pendekatan studi etnografi virtual. Metode pendekatan tersebut dilakukan untuk melihat fenomena sosial dan budaya yang terjadi dalam dunia siber (Nasrullah, 2014: 171-172). Peneliti melihat bahwa stiker-stiker yang dipilih dan digunakan oleh para generasi milenial pengguna sosial media aplikasi Line grup memiliki arti dan realitas sosial, maka daripada itu paradigm yang digunakan tentunya merupakan paradigm konstruktivisme. Paradigma tersebut menggambarkan bahwa setiap individu mengintepretasi dan bertindak berdasarkan konsepkonsep yang ada dalam caranya berpikir (Ardianto dan Q-Anees, 2009: 151).

Teknik pengumpulan data yang dilakukan adalah interview mendalam baik secara online maupun off-line. Hal ini dilakukan untukmengklarifikasi dan mengkonfirmasi terhadap wawancara yang telah dilakukan secara online. Pola wawancara online dan offline ini merupakan pola yang harus dilakukan peneliti etnografi virtual, untuk mencegah bias informasi dan ketidakpastian validasi data (Arif, 2012). Teknik pengumpulan data lainnya adalah studi dokumentasi dan observasi.

Observasi yang dipilih merupakan observasi complete participant: "the researcher is fully engaged with the people he or she is observing" (Creswell, 2013). Peneliti masuk ke dalam kelompok grup Line di mana para subjek penelitian (informan) bersosialisasi, peneliti berinteraksi dan juga bersosialisasi dengan mereka secara online maupun off-line. Observasi partisipan secara on line mengamati secara langsung perkembangan komunitas atau kelompok, melihat dinamika atau isu, tema yang dibicarakan dan sekaligus mencermati verbal dan non verbal yang digunakan dalam percakapan. Stikerstiker yang digunakan merupakan salah satu percakapan yang dikategorikan 
secara non verbal. Penelitian ini menjadi menarik ketika stiker-stiker tidak hanya mengantikan apa yang ingin disampaikan dalam kelompok grup Line namun juga stiker tersebut menjadi slaha satu cara membangun citra dirinya. (mengkonstruksiPersonal branding)

Secara off line, pengamatan partisipan, digunakan peneliti untuk lebih memahami karakter individu/kelompok ketika berada di dunia nyata, mencermati kebiasaankebiasaan yang dilakukan didunia maya memiliki kaitan atau mempengaruhi kebiasaan-kebiasaan yang dilakukan di dunia online atau sebaliknya(Arif, 2012).

\section{HASIL DAN PEMBAHASAN}

Informan yang menjadi subjek penelitian ini merupakan mereka yang disebut sebagai generasi milenial atau generasi $\mathrm{Y}$, mereka lahir pada tahun 1990-an dan awal 2000-an. Informan terdiri dari 14 orang yang mengakui bahwa dirinya aktif dalam media sosial Line. Mereka juga tergabung dalam satu kelompok Line Grup. Grup tersebut dinamakan grup 'Catroops'. Grup 'Catroops' ini adalah mereka yang terpilih menjadi asisten guru bahasa Inggris pada sebuah sekolah bahasa Inggris di Bandung. Grup tersebut dibuat untuk mempermudah komunikasi di antara anggota Catroops. Grup tersebut sudah berjalan dari tahun 2015 .

$$
\text { Grup 'Catroops' yang }
$$

beranggotakan asisten guru bahasa Inggris membuat peneliti melakukan interview secara online offline dalam bahasa Inggris, namun diterjemahkan untuk keperluan penelitian ini. Informan-informan ini mengakui bahwa mereka sering menggunakan Line stiker baik untuk mempresentasikan dirinya maupun untuk mempermudah maksudnya dalam sebuah percakapan dalam aplikasi Line dengan anggotaanggota yang terdapat dalam grup Line tersebut maupun di luar grup. Sebagian besar informan yang menjadi subjek penelitian ini mengakui bahwa Personal branding dalam media sosial memiliki peran yang besar, yang bisa ditunjukkan melalui budaya tutur yang mereka gunakan dalam media sosial.

Personal Branding dalam media sosial seperti yang telah dipaparkan sebelumnya sekarang memiliki peran yang penting dalam kehidupan sosial. Ilfa salah satu informan mengatakan bahwa pada era ini semua orang menggunakan smartphones dan juga media sosial, menurutnya apapun yang dikemukakan pada media sosial itu mencerminkan identitas kita, maka pencitraan diri dalam sosial media diperlukan.

'Catroops' merupakan mereka yang rata-rata berumur antara 18 hingga 23 tahun. Data menyebutkan bahwa mereka yang berumur 18-29 tahun paling memiliki tendensi yang tinggi dalam menggunakan media sosial (Perrin, 2015). Data tersebut mengasumsikan mereka yang merupakan generasi milenial merupakan mereka yang perlu memperhatikan personal branding mereka lewat media sosial.

Perilaku seseorang dalam media sosial dapat mempengaruhi persepsi calon pemberi kerja mengenai diri seseorang(Johnson K. M., 2017). Informan-informan yang tergabung dalam 'catroops' memiliki supervisor yang mengawasi tindak tinduk mereka baik dalam grup itu sendiri maupun di media sosial lainnya seperti di Instagram, twitter maupun facebook. Hal ini menyadarkan mereka bagaimana budaya tutur mereka dalam Line grup tersebut diperhatikan. Sehingga, mau tidak mau mereka berhati-hati dalam 
bertutur yang sekaligus mengungkapkan citra dirinya dalam media sosial.

Sebagian besar informan yang menjadi subjek penelitian ini mengakui bahwa stiker-stiker yang mereka pilih untuk personal branding mereka bersifat positif dan tidak merugikan orang lain. Lebih tepatnya, mereka menginginkan stiker yang dikeluarkan oleh diri mereka secara sengaja dapat memberikan kenyamanan bagi siapapun yang melihatnya. Budaya tutur yang digunakan oleh anggota 'Catroops' ini berdasarkan pengamatan peneliti terlihat sudah terinternalisasi dan menjadi bagian nyata identitas masingmasing informan. Pada observasi yang di lakukan secara off-line, karakter stiker yang dipilih dalam grup Line kurang lebih mempresentasikan identitas mereka secara off-line.

Berikan adalah tabel 1 yang menunjukkan pilihan-pilhan stiker para informan.

Tabel 1: Stiker dan Brand yang ingin disampaikan Informan

\begin{tabular}{|c|c|c|}
\hline No & Informan & $\begin{array}{c}\text { Brand yang } \\
\text { ingin } \\
\text { disampaikan }\end{array}$ \\
\hline 1 & Adelia & $\begin{array}{l}\text { ". because } \\
\text { whatever it's } \\
\text { good or bad I like } \\
\text { to appreciate } \\
\text { other people.." } \\
\text { Citra diri yang } \\
\text { ingin } \\
\text { dipresentasikan: } \\
\text { Adelia } \\
\text { merupakan } \\
\text { seseorang yang } \\
\text { menghargai } \\
\text { orang lain } \\
\text { meskipun hal } \\
\text { tersebut baik } \\
\text { ataupun buruk. } \\
\text { Observasi off } \\
\text { line: } \\
\text { Adelia seseorang }\end{array}$ \\
\hline
\end{tabular}

\begin{tabular}{|c|c|c|}
\hline & & $\begin{array}{l}\text { yang santun dan } \\
\text { sering tersenyum, } \\
\text { melakukan segala } \\
\text { sesuatu dengan } \\
\text { baik dan teratur. }\end{array}$ \\
\hline 2 & Vte & $\begin{array}{l}\text { “. I am full of } \\
\text { love.. I like to } \\
\text { spread the love } \\
\text { everywhere to } \\
\text { anyone..I'm } \\
\text { happy to see } \\
\text { people around } \\
\text { me happy.. it is } \\
\text { one way to make } \\
\text { myself confident } \\
\text { and happy too' } \\
\text { Citra diri yang } \\
\text { ingin } \\
\text { dipresentasikan: } \\
\text { Vte adalas } \\
\text { seseorang yang } \\
\text { ingin } \\
\text { menyebarkan } \\
\text { kasih sayang } \\
\text { kepada siapapun. } \\
\text { Hal ini juga dapat } \\
\text { membangkitkan } \\
\text { rasa percaya } \\
\text { dirinya. } \\
\text { Observasi off } \\
\text { line: } \\
\text { Vte seseorang } \\
\text { yang selalu ceria } \\
\text { dan selalu } \\
\text { bergembira } \\
\text { apapun } \\
\text { kondisinya. Ia } \\
\text { selalu ingin } \\
\text { membuat orang } \\
\text { sekitarnya } \\
\text { nyaman. }\end{array}$ \\
\hline 3 & Sarah & $\begin{array}{l}\text { ".. always try to } \\
\text { be strong.." } \\
\text { Citra diri yang } \\
\text { ingin } \\
\text { dipresentasikan: } \\
\text { Sarah ingin } \\
\text { dilihat sebagai } \\
\text { seseorang yang }\end{array}$ \\
\hline
\end{tabular}




\begin{tabular}{|c|c|c|}
\hline & & $\begin{array}{l}\text { kuat, dalam hal } \\
\text { ini kuat akan } \\
\text { terpaan kesulitan } \\
\text { dunia } \\
\text { Observasi off } \\
\text { line: } \\
\text { Ia mencoba terus } \\
\text { melakukan hal } \\
\text { terbaik dan akan } \\
\text { menghadapi } \\
\text { kesalahannya } \\
\text { penuh dengan } \\
\text { rasa kesatria }\end{array}$ \\
\hline 4. & Kafani & $\begin{array}{l}\text { "I want to share } \\
\text { love to everyone" } \\
\text { Citra diri yang } \\
\text { ingin } \\
\text { dipresentasikan: } \\
\text { Kafani } \\
\text { merupakan } \\
\text { seseorang yang } \\
\text { menyebarkan } \\
\text { rasa sayangnya } \\
\text { pada orang lain } \\
\text { Observasi } \\
\text { line: } \\
\text { Kafani lebih } \\
\text { banyak diam dan } \\
\text { pasif, namun } \\
\text { selalu berusaha } \\
\text { untuk datang } \\
\text { pada tiap acara } \\
\text { dengan disiplin } \\
\text { dan mengikuti } \\
\text { semua peraturan } \\
\text { yang ada. }\end{array}$ \\
\hline 5 . & Ilfa & $\begin{array}{l}\text { "I need to be } \\
\text { spiritful } \\
\text { wherever, } \\
\text { whenever and } \\
\text { whatever the } \\
\text { situation is.." } \\
\text { Citra diri yang } \\
\text { ingin } \\
\text { dipresentasikan: } \\
\text { Ilfa merupakan } \\
\text { seseorang yang } \\
\text { ingin dilihat } \\
\text { sebagai seseorang yang } \\
\text { seseola semangat } \\
\text { selalu }\end{array}$ \\
\hline
\end{tabular}

\begin{tabular}{|c|c|c|}
\hline & & $\begin{array}{l}\text { menjalankan } \\
\text { kehidupannya. } \\
\text { Observasi off } \\
\text { line: } \\
\text { Ilfa yang juga } \\
\text { bekerja sebagai } \\
\text { petani kopi, } \\
\text { meskipun secara } \\
\text { fisik ia terlihat } \\
\text { lelah, namun } \\
\text { dalam acara- } \\
\text { acara 'catroops' } \\
\text { ia selalu berusaha } \\
\text { terlihat semangat. }\end{array}$ \\
\hline 6. & $\mathrm{Zk}$ & $\begin{array}{l}\text { "because no one } \\
\text { know what is } \\
\text { behind that } \\
\text { smile" } \\
\text { Citra diri yang } \\
\text { ingin ingin } \\
\text { dipresentasikan: } \\
\text { Zk sk off } \\
\text { menpresentasikan } \\
\text { dirinya sebagai } \\
\text { seseorang yang } \\
\text { sulit ditebak } \\
\text { Observasi } \\
\text { line: } \\
\text { Zk termaksud } \\
\text { seseorang yang } \\
\text { tidak terlalu } \\
\text { membuka dirinya } \\
\text { namun sangat } \\
\text { aktif dalam } \\
\text { bersosialisasi. }\end{array}$ \\
\hline 7. & Satrio & $\begin{array}{l}\text { "I am a happy } \\
\text { person..I take } \\
\text { everything easy } \\
\text { with no hard } \\
\text { feelings and keep } \\
\text { trying to spread } \\
\text { good vibes" } \\
\text { Citra diri yang } \\
\text { ingin ingin } \\
\text { dipresentasikan: } \\
\text { Satrio adalah } \\
\text { menunjukkan } \\
\text { dirinya yang } \\
\text { seseorang yagia } \\
\text { selalu bahagiona }\end{array}$ \\
\hline
\end{tabular}




\begin{tabular}{|c|c|c|}
\hline & & $\begin{array}{l}\text { dan ingin terus } \\
\text { menyebarkan } \\
\text { getaran positif } \\
\text { pada } \\
\text { lingkungannya } \\
\text { Observasi off } \\
\text { line: } \\
\text { Satrio selalu bisa } \\
\text { membawa situasi } \\
\text { menjadi lucu dan } \\
\text { nyaman untuk } \\
\text { semua orang } \\
\text { disekelilingnya }\end{array}$ \\
\hline 8. & Tesa & $\begin{array}{l}\text { "if we smile, life } \\
\text { will be easier" } \\
\text { Citra diri yang } \\
\text { ingin } \\
\text { dipresentasikan: } \\
\text { Tesa merasa } \\
\text { bahwa senyuman } \\
\text { merupakan kunci } \\
\text { akan kehidupan } \\
\text { yang lebih baik. } \\
\text { Observasi } \\
\text { line: } \\
\text { Tesa selalu } \\
\text { tersenyum } \\
\text { meskipun dalam } \\
\text { anggota } \\
\text { 'Catroops' ia } \\
\text { yang termuda. } \\
\text { Tidak begitu aktif } \\
\text { namun selalu } \\
\text { berusaha. }\end{array}$ \\
\hline 9. & Cecep & $\begin{array}{l}\text { "I am a happy } \\
\text { person.." } \\
\text { Citra diri yang } \\
\text { ingin } \\
\text { dipresentasikan: } \\
\text { Cecep adalah } \\
\text { seseorang yang } \\
\text { selalu bahagia } \\
\text { dan bersyukur } \\
\text { Observasi off } \\
\text { line: } \\
\text { Cecep adalah } \\
\text { seseorang yang } \\
\text { selalu bergembira } \\
\text { dan tertawa dan }\end{array}$ \\
\hline
\end{tabular}

\begin{tabular}{|c|c|c|}
\hline & & $\begin{array}{l}\text { berusaha selalu } \\
\text { aktif secara off- } \\
\text { line. }\end{array}$ \\
\hline 10. & Sony & $\begin{array}{l}\text { "It doesn't make } \\
\text { other people } \\
\text { angry" } \\
\text { Citra diri yang } \\
\text { ingin } \\
\text { dipresentasikan: } \\
\text { Sony ingin orang } \\
\text { lain merasa } \\
\text { nyaman dan tidak } \\
\text { tersingung } \\
\text { Observasi off } \\
\text { line: } \\
\text { Sony seseorang } \\
\text { yang selalu ceria } \\
\text { dan bersahabat } \\
\text { dengan siapapun } \\
\text { disekelilingnya }\end{array}$ \\
\hline 11. & & $\begin{array}{l}\text { "it represent me } \\
\text { everyday" } \\
\text { " I like to } \\
\text { surprise } \\
\text { everyone" } \\
\text { Citra diri yang } \\
\text { ingin } \\
\text { dipresentasikan: } \\
\text { Naufal seseorang } \\
\text { yang sibuk } \\
\text { melakukan tugas- } \\
\text { tugas kuliah. Ia } \\
\text { juga seseorang } \\
\text { yang ingin selalu } \\
\text { mengejutkan } \\
\text { orang lain. } \\
\text { Observasi off } \\
\text { line: } \\
\text { Naufal seseorang } \\
\text { yang berusaha } \\
\text { selalu ada untuk } \\
\text { orang lain } \\
\text { meskipun dirinya } \\
\text { sibuk dengan } \\
\text { perkuliahan }\end{array}$ \\
\hline 12. & Fajira & $\begin{array}{l}\text { "It looks happy" } \\
\text { Citra diri yang } \\
\text { ingin } \\
\text { dipresentasikan: } \\
\text { Fajira seseorang }\end{array}$ \\
\hline
\end{tabular}




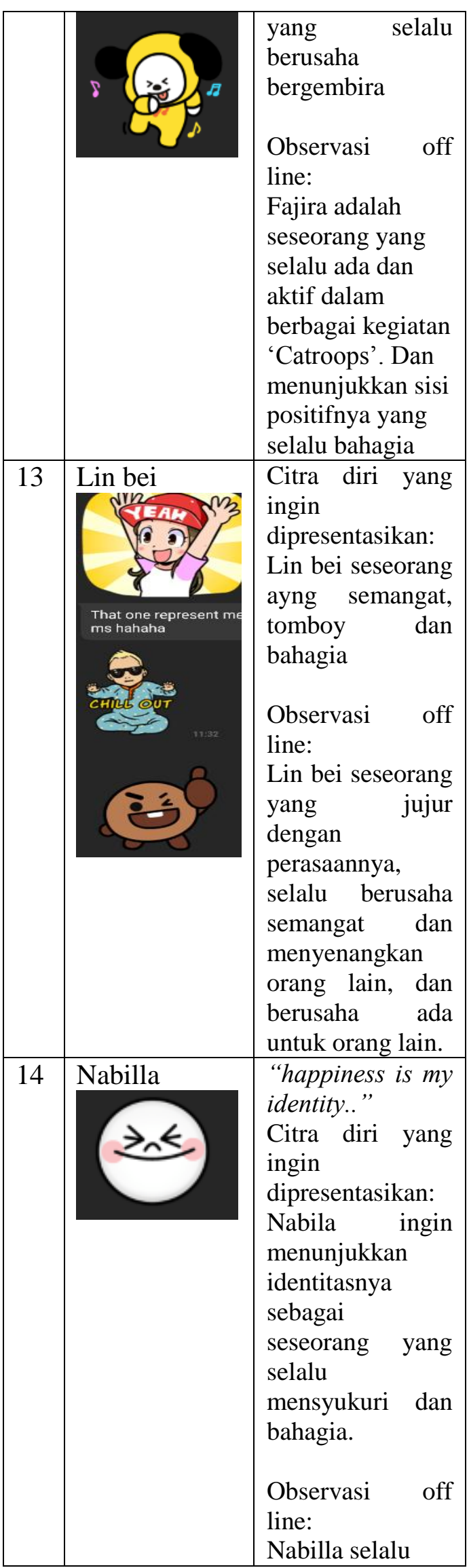

\begin{tabular}{|l|l|}
\hline & $\begin{array}{l}\text { berusaha untuk } \\
\text { menyenangkan } \\
\text { orang lain dengan } \\
\text { melakukan segala } \\
\end{array}$ \\
& sesuatu dengan \\
& baik dan teratur. \\
& Selalu terlihat \\
& tersenyum dan \\
& gembira. \\
\hline
\end{tabular}

Satrio salah satu informan yang merupakan informan ke 7 pada tabel diatas, iamemilih stiker tersebut karena ia merasa dirinya adalah seseorang yang bahagia. Nilai budaya yang terinternalisasi dalam dirinya menunjukkan pilihan stikernya. Ia mengakui bahwa dirinya melihat kehidupan ini untuk tidak di bawa sulit, dan harus selalu menyebarkan getaran positif. Stiker tersebut dianggap bisa menyebarkan energi positif bagi yang melihatnya.

Vte merasa dirinya adalah seseorang yang penuh kasih sayang. Itu adalah nilai budaya yang terinternalisasikan dalm dirinya, maka ia akan memilih stiker yang dapat menunjukkan nilai budaya tersebut. Stiker tersebut harus bisa menunjukkan rasa sayang yang ia tebarkan kepada orang-orang disekelilingnya. Hal tersebut akan membuat dirinya merasa lebih bahagia.

Sony memilih stiker-stiker yang berjudul 'tatan sticker'. Ia memahami bagaimana media sosial dengan mudah dapat memberikan kesalahan interpretasi maka stiker tatan ini dianggap tidak akan membuat siapapun marah, bahkan bisa membuat orang lain tertawa ketika melihatnya.

Nabila memilih stiker muka yang tersenyum. Menurutnya stiker tersebut harus menjadi identitasnya yang menunjukkan seseorang yang selalu bahagia. Nilai budaya yang terinternalisasi dalam dirinya 
menunjukkan bahwa ia ingin memberikan kebahagian bagi siapapun yang melihat stiker tersebut. Dari wawancara dengan nabilla secara offline, ia merasa generasi milenial ini kurang bahagia. Ini diakui sebagai akibat dari ketergantungan generasi tersebut dengan smartphones atau juga persaingan yang lebih keras di dunia nyata, sehingga prestasi seseorang sangat penting.Personal branding dalam media sosial menjadi sangat penting karena persaingan ketat yang terjadi sekarang ini. Penting untuk melalukan personal branding karena pada hakekatnya manusia sekarang mencari tahu tentang seseorang itu lewat akun media sosial mereka, dan tidak jarang mereka langsung percaya dengan apa yang ada dalam akun media sosial tersebut.

Fajira pada wawancara offline juga menyatakan bahwa personal branding dalam era digital sangat penting karena era tersebut mendorong manusia untuk melakukannya. Pada hakekatnya manusia pada era sekarang hidup dalam era yang serba digital. "pencitraan itu penting asal ga berlebihan dan caranya yang bener. Itu buat self branding' (Cecep, 2019). Cecep merasa media sosial memiliki peran dalam mengkonstruksi identitas kita.

Personal branding dalam media sosial sebagai sebuah budaya tutur digital dianggap penting pada masa ini menurut ilfa. Ini disebabkan oleh jaman era digital itu sendiri, yang mendorong semua orang untuk selalu menggunakan smartphones. Ilfa sangat setuju apabila identitas yang diperlihatkan dalam media sosial merupakan identitas yang diri kita yang sebenarnya.

Lin bei (informan ke-13) merasa stiker (anak perempuan yang bergembira) mempresentasikan dirinya yang sesungguhnya. 'it is so me' (lin, 2019). Apalagi ketika ia sedang setuju pada sebuah pembahasan dan merasa senang. Stiker tersebut mempresentasikan sosok tomboy namun tetap perempuan. Ia ingin orang lain mengidentifikasikan dirinya seperti itu. 'the looking-glass self' yang dikemukakan oleh Cooley dalam Mulyana (2001) mengatakan bahwa konsep-diri individu secara signifikan ditentukan oleh apa yang ia pikirkan tentang pikiran orang lain mengenai dirinya, sehingga apa yang menjadi respond dari orang lain terhadap dirinya diinternalisasikan secara subjektif. Lin bei mengakui bahwa orang lain yang terdekat dengannya menganggapnya sebagai seseorang yang 'tomboy'. Sehingg pada hakekatnya ia mencoba merealisasikannya melalui stiker-stiker yang ia pilih dan gunakan.

Pemilihan dan penggunaan stiker pada Line sebagai budaya tutur generasi milenial yang tergabung dalam grup 'Catroops' ini sebagian besar konsisten dalam penggunaannya. Mereka berusaha untuk terus mempergunakan stiker-stiker tersebut dalam setiap kesempatan mereka ketika berinteraksi. 'Developing a Personal brand is an ongoing process that involves interactions with others face-to face communication and online' seperti yang diungkapkan Hearn (2008), Khedler (2015), Peters (1997) dan Vitberg (2009) (Johnson K. M., 2017). Perkembangan sebuah personal brand merupakan proses yang berkelanjutan yang melibatkan interaksi dengan orang lain baik secara langsung maupun online.

Selain Personal branding, stiker-stiker yang dipilih dan digunakan juga berguna untuk menekankan maksud pembicaraannya secara nonverbal, dan pengunaan stiker tersebut dilakukan pada situasi dan kondisi yang tepat. Sebagian besar informan mengakui asal mula pemilihan 
stiker itu adalah karena rasa suka-nya pada stiker tersebut karena terlihat lucu, unik dan menyenangkan. Kemudian stiker tersebut memiliki kegunaan lainnya yaitu menekankan maksud dan tujuannya bahkan perasaannya.

Armien salah supervisor dalam grup 'Catroops' yang juga berprofesi sebagai guru mengakui bahwa iajarang menggunakan sticker pada saat pembicaraan yang formal, hanya sebatas stiker yang lebih menekankan sebuah pesan kalimat. Stiker tidak iagunakan pada percakapan yg serius. Ia seperti anggota 'Catroops' yang lain memilih stiker 'Parampa'(Gambar 2) karena terlihat menyebalkan namun juga sederhana. Ia ingin menggambarkan muka sarkastik, namun tidak ingin mengidentifikasikan dirinya seagai orang yg sarkastik. Hanya dalam beberapa peristiwa, contoh ketika muridnya mengirimkan pesan online untuk meminta ijin bahwa dirinya akan telat datang, dan ia merasa memiliki hubungan yang dekat dengan murid tersebut, kemudian dia akan menggunakan stiker tersebut

Stiker tersebut diggunakan untuk mendukung sebuah pembicaraan, karena Armien sangat memahami bagaimana percakapan dalam media sosial mengurangi banyak elemen non verbal yang bisa mengarah pada kesalahpahaman.Ia juga mengakui penggunaan stiker diharapkan dapat memberikan respon yang cepat secara nonverbal namun dapat dipahami secara baik bagi siapapun yang melihatnya.

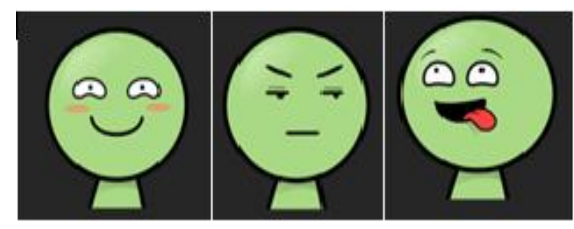

Gambar 2: Stiker Parampa

(Sumber: Aplikasi Line).
Zk memiliki banyak stiker pada Line, ini diakui sebagai keinginannya untuk menyombongkan kepada temantemanyanya karena ia memiliki stikerstiker banyak yang unik. Pemilihan stiker oleh Zk terbilang unik, ia merasa bahwa stiker-stiker yang ia tunjukkan hanya akan dipahami oleh orang-orang yang 'peka', mereka akan memahami perasaanya. Salah satu contohnya adalah penggunaan stiker tengkorak (gambar 3). Pada hasil wawancara dengan $\mathrm{Zk}$, ia ingin mengatakan bahwa dirinya merasa mati rasa, kecewa, sedih, dan menyesal pada sebuah pembahasan yang sedang diperpincangkan dalam grup Line.

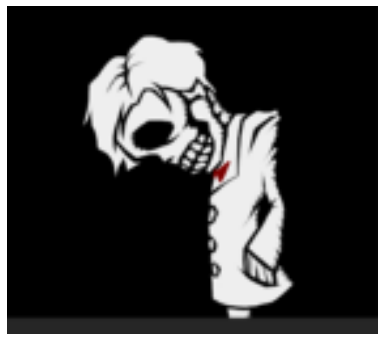

Gambar 3: Stiker tengkorak

(Sumber: Aplikasi Line)

Sesuai dengan paradigm konstruktivis yang menyatakan bahwa individu bukan korban fakta sosial, namun sangat kreatif dalam mengkonstruksi dunia sosialnya. Maka dalam hal ini, para informan memiliki kebebasan secara kreatif dalam memilih stiker-stiker yang dapat mengidentifikasi dirinya yang sekaligus sebagai bentuk sosialisasi personal brand-ingnya.

\section{SIMPULAN}

Uraian diatas mengemukakan beberapa kesimpulan dalam penelitian ini, yaitu: 
1. Mereka biasanya membeli stiker yang dapat mempresentasikan dirinya dan perasaan mereka pada sebuah subjek pembahasan untuk mendukung personal branding mereka dalam grup Line,

2. Generasi milenial menggunakan stiker untuk; mendukung maksud mereka dalam sebuah diskusi, ketika mereka tidak dapat menjelaskan sesuatu lewat perkataan verbal, ketika mereka terpaksa untuk menanggapi sesuatu dengan cepat dan karena stiker tersebut dianggap unik dan lucu

\section{DAFTAR PUSTAKA}

Ambarwati, A., \& Raharjo, S. T. (2018). Prinsip Kepemimpinan Character of A Leader pada Era Generasi Milenial. Philanthropy Journal of Psyocology , 114-127.

Arief, L. (2019, Januari 26). Why personal branding is important in social media. (S. S. Indriani, Interviewer)

Arif, M. C. (2012). Etnografi Virtual, Sebuah Tawaran Metodelogi Kajian Media Berbasis Virtual. Jurnal Ilmu Komunikasi , 165-179.

Basrowi, \& Sukidin. (2002). Metode Penelitian Kualitatif Perspektif Mikro. Surabaya: penerbit Insan Cendekia

Creswell, J. W. (2013). Qualitative Inquiry \& Research Design, Choosing Among Five Approaches. California: SAGE Publication, Inc.

Johnson, K. M. (2017). The Importance of Personal Branding in Social Media: Educating Students to Create and Mange their Personal Brand. International Journal of Education and Social Science, 21-27.
Karaduman, I. (2013). The Effect of Social Media on Personal Branding Efforts of Top Level Executives. Procedia - Social and Behavioral Sciences , 465-473.

Mulyana, D. (2001). Metode Penelitian Kualitatif. Bandung: PT Remaja Rosdakarya.

Perrin, A. (2015). Social Media Usage: 2005-2015 65\% of adults now use social networking sites - a nearly tenfold jump in the past decade. pew Research Center.

Putra, Y. S. (2016). Theoritical Review: Teori Perbedaan Generasi. Jurnal Ilmiah Among Makarti , 123-134.

Republika, P. D. (2016, 12 26). Republika.co.id. Retrieved 2 12, 2019, from Rebublika website: https://www.republika.co.id

Sawyer, R. (2011). The Impact of New Social Media on Intercultural Adaptation. Retrieved Januari 16, 2019, from DiigitalCommons@URL: https://digitalcommons.uri.edu

Sherlyanita, A. K., \& Rakhmawati, N. A. (2016). Pengaruh dan Pola Aktivitas Penggunaan Internet serta Media Sosial pada Siswa SMPN 52 Surabaya. Journal of Information Systems Engeneering and Buisness Intelligence, 17-22.

Waterman, A. S, (1984). Identity formation: Discovery or Creation? Journal of Early Adolescence, Vol 4, Issue 4. Sage Journals 